RECLAIMING THE PETITION CLAUSE 
This page intentionally left blank 


\section{ReCLAIMING THE}

\section{Petition Clause}

Seditious Libel, "Offensive" Protest, and the Right to Petition the Government for a Redress of Grievances

Ronald J. Krotoszynski, Jr.

Yale UNIVERSITY PRESS

New Haven G London 
Published with assistance from the foundation established in memory of Calvin Chapin of the Class of 1788 , Yale College.

Copyright (C) 2012 by Yale University.

All rights reserved.

This book may not be reproduced, in whole or in part, including illustrations, in any form (beyond that copying permitted by Sections 107 and 108 of the U.S. Copyright Law and except by reviewers for the public press), without written permission from the publishers.

Yale University Press books may be purchased in quantity for educational, business, or promotional use. For information, please e-mail sales.press@yale.edu (U.S. office) or sales@yaleup.co.uk (U.K. office).

Set in Electra type by IDS Infotech Ltd., Chandigarh, India.

Printed in the United States of America.

Library of Congress Cataloging-in-Publication Data

Krotoszynski, Ronald J., 1967-

Reclaiming the petition clause : seditious libel, "offensive" protest, and the right to petition the government for a redress of grievances / Ronald J. Krotoszynski, Jr.

$$
\text { p. } \mathrm{cm} \text {. }
$$

Includes bibliographical references and index.

ISBN 978-0-300-14987-6 (cloth : alk. paper) 1. Petition, Right of-United States.

I. Title.

$$
\begin{aligned}
& \mathrm{KF}_{47} 80 . \mathrm{K}_{7} 6_{2012} \\
& 323.4^{\circ} 80973-\mathrm{dc} 23
\end{aligned}
$$

A catalogue record for this book is available from the British Library.

This paper meets the requirements of ANSI/NISO Z39.48-1992

(Permanence of Paper).

10987654321 
This book is dedicated to the memory of Judge Frank M. Johnson Jr. (19181999), for whom I had the privilege of serving as a law clerk. Judge Johnson served with great distinction - and courage-on the federal bench in Montgomery, Alabama, during some of the most tumultuous years of the civil rights movement. As a district court judge, Johnson presided over many of the most important civil rights cases aimed at securing federal constitutional rights in Alabama.

Judge Johnson firmly believed that, if permitted to operate freely and openly, the democratic process could be relied upon to correct many constitutional injustices through the regular functioning of the legislative process. For example, his opinion in Williams v. Wallace, 240 F. Supp. 100 (M.D. Ala. 1965), in which he issued an injunction permitting the iconic Selma-to-Montgomery March to go forward, reflects and incorporates this deep-seated faith in democracy and the democratic process. Judge Johnson appreciated the centrality of petitioning to the project of democratic self-government, and from the bench he worked to ensure that government would remain both accessible and accountable to its citizens through peaceful petitioning activity seeking a redress of constitutional grievances.

Judge Johnson's faith in the possibility of peaceful social reform through the operation of the democratic process, at a time when tempers ran high and political violence constituted an omnipresent-albeit despicable-reality, can and should serve as an example to us today. No one can deny the real and pressing security issues that exist in the post-9/11 world; indeed, we can, should, and must take seriously the threat of political violence as an illegitimate means of seeking to alter government practices and policies. For a democratic people effectively to oversee the government and its officers, however, citizens must have the ability to access and engage their government and its officials about matters of public concern. Moreover, government has a duty to engage its citizens and respond to their concerns and criticisms. Judge Johnson understood that petitioning activity lies at the very heart of this democratic feedback loop.

Judge Johnson's remarkable opinion in Williams stands as a testament to this important truth; his unwavering commitment to safeguarding the right of petition, even if exercised in a hybrid form that annexed speech, assembly, and association rights, provided significant motivation - indeed, inspiration - to me in pursuing this project. Accordingly, I dedicate this book as a tribute to Judge Johnson's remarkable judicial contributions to helping secure constitutionally protected expressive freedoms in the most difficult of times and places. His life's work and legacy can and should inspire us all to consider carefully the importance of safeguarding fundamental expressive freedoms, including the right of petition, in the contemporary United States and also in the larger world. 
This page intentionally left blank 